\title{
Management of Raynaud's Syndrome following local anesthesia in dentistry
}

\author{
Tratamento da Síndrome de Raynaud após anestesia local odontológica \\ Manejo del síndrome de Raynaud después de la anestesia dental local
}

Received: 12/28/2021 | Reviewed: 01/03/2022 | Accept: 01/15/2022 | Published: 01/17/2022

\author{
Christopher Cadete de Figueiredo \\ ORCID: https://orcid.org/0000-0001-7251-7605 \\ University of Pernambuco, Brazil \\ E-mail: christopher.figueiredo@upe.br \\ José Lacet de Lima Júnior \\ ORCID: https://orcid.org/0000-0001-5355-6457 \\ Dentists' Syndicate of Paraíba, Brazil \\ E-mail: lacetbmf@gmail.com \\ João Luiz Gomes Carneiro Monteiro \\ ORCID: https://orcid.org/0000-0001-6826-0798 \\ University of Pernambuco, Brazil \\ E-mail: joaoluiz.monteiro@upe.br \\ Ricardo José De Holanda Vasconcellos \\ ORCID: https://orcid.org/0000-0002-7934-5743 \\ University of Pernambuco, Brazil \\ E-mail: ricardo.holanda@upe.br
}

\begin{abstract}
Raynaud's Syndrome (RS) is generally characterized by either ischemic or hyperemic symptoms and is relatively frequent in patients hypersensitive to cold or with emotional stress. This phenomenon usually cease after no more than some minutes, however, can persist for hours Its treatment is aimed at promoting vasodilation i.e., warming procedures. Anxiety control prior to surgical procedure helps in prevention the occurrence of RS. Despite RS following local dental anesthesia being rare, dentists must be prepared to manage. There are limited reports of patients with this syndrome during dental procedures, so here we describe a case of a patient who has undergone a surgical implant installation and who developed primary RS following local anesthesia using an adrenergic vasoconstrictor, as well as the management of this complication in dental office. Dentists should be able to recognize the RS and follow the appropriate guidelines available, after control the case the patient should also be referred to a general physician for further investigations.
\end{abstract}

Keywords: Raynaud disease; Local anesthesia; Ischemia.

\section{Resumo}

A Síndrome de Raynaud (SR) é geralmente caracterizada por sintomas isquêmicos ou hiperêmicos e é relativamente frequente em pacientes hipersensíveis ao frio ou com estresse emocional. Este fenômeno geralmente cessa após não mais do que alguns minutos, no entanto, pode persistir por horas. Seu tratamento visa promover a vasodilatação, ou seja, procedimentos de aquecimento. $\mathrm{O}$ controle da ansiedade antes do procedimento cirúrgico auxilia na prevenção da ocorrência da SR. Apesar da SR após anestesia local odontológica ser rara, os dentistas devem estar preparados para o tratamento. Existem relatos limitados de pacientes com essa síndrome durante procedimentos odontológicos, então aqui nós descrevemos um caso de um paciente que foi submetido a uma cirurgia para instalação de implante dentário e que desenvolveu SR primária após anestesia local com vasoconstritor adrenérgico, bem como o tratamento dessa complicação no consultório odontológico. O dentista deve ser capaz de reconhecer a SR e seguir as devidas orientações disponíveis, após o controle do caso o paciente também deve ser encaminhado a um clínico geral para novas investigações.

Palavras-chave: Doença de Raynaud; Anestesia local; Isquemia.

\section{Resumen}

El Síndrome de Raynaud (SR) se caracteriza generalmente por síntomas isquémicos o hiperémicos y es relativamente frecuente en pacientes hipersensibles al frío o con estrés emocional. Este fenómeno generalmente desaparece después de unos minutos, sin embargo, puede persistir durante horas.Su tratamiento tiene como objetivo promover la vasodilatación, es decir, los procedimientos de calentamiento. El control de la ansiedad antes del procedimiento quirúrgico ayuda a prevenir la aparición de SR. A pesar de que el SR después de la anestesia dental local es poco común, los dentistas deben estar preparados para manejarlo. Hay informes limitados de pacientes con este síndrome durante procedimientos dentales, por lo que aquí describimos el caso de un paciente que se ha sometido a una instalación quirúrgica de implantes y que desarrolló RS primario después de la anestesia local con un vasoconstrictor 
adrenérgico, así como el manejo de esta complicación. en consultorio dental. Los dentistas deben ser capaces de reconocer el RS y seguir las pautas apropiadas disponibles, después de controlar el caso, el paciente también debe ser derivado a un médico general para realizar más investigaciones.

Palabras clave: Enfermedad de Raynaud; Anestesia local; Isquemia.

\section{Introduction}

Initially described in 1862, RS is characterized by episodic ischemia frequently identified in patients hypersensitive to cold or with emotional stress (Milet et al., 1953), (Pope, 2007), (Landry, 2013). Depending on variables such as the population analyzed, climate of the region, and clinical outcome definition, the prevalence of RS worldwide ranges from $0.5 \%$ to $20 \%$ (Voulgari et al., 2000), (Suter et al., 2005), (De Angelis et al., 2006).

Raynaud's syndrome is characterized by local vasoconstriction and blanching especially in the extremities, which is followed by cyanosis and rebound hyperemia surrounding the affected site (Landry, 2013), (Jackson, 2006) (Kayser et al., 2009). Therefore, the skin color changes are classically described in three subsequent phases: pallor (ischemic phase), cyanosis (caused by reduced blood flow) and redness (reactive hyperemia / reperfusion) (Kayser et al., 2009), (Herrick, 2012). Heidrich (2010) reports that the attacks usually cease after no more than some minutes (average 23 minutes), however, can persist for hours.

Landry (2013) explains that the underlying pathophysiologic mechanisms of this disease are not well established, however, it has been suggested that alterations in peripheral adrenoceptor activity might be implicated. As such, it might be either an overexpression or hyperactivity of postsynaptic alpha-2 receptors resulting in an enhanced smooth muscle contraction. The diagnosis of RS remains primarily clinical and is based on patient's report of cold or emotionally induced skin changes.

There are limited reports of patients with this syndrome during dental procedures, so this paper describes the case of a patient schedule for dental implant placement and who developed RS following local anesthesia using an adrenergic vasoconstrictor.

\section{Case Report}

A 63-year old white male patient was scheduled for dental implant placement in the region of the mandibular right second molar. He already had a dental implant installed in the region corresponding to the lower right first molar. His medical history included type 2 diabetes (treated with metformin for five years). The patient reported sporadic use of alcohol and tobacco smoking. At the day of the surgery, a self-aspirating local anaesthetic syringe was used to perform infiltrative local anesthesia with $1.8 \mathrm{ml}$ of $4 \%$ articaine with epinephrine $(1: 100,000)$ in the region of dental implant placement. After approximately 2 minutes after infiltration, the patient reported a "great burning" in the neck and face, adjacent to the anesthetized site. An ischemic area became evident on the skin near the carotid arteries and over the facial artery distribution. This last for about 10 minutes. This was followed by generalized hyperemia adjacent to the ischemic site, as seen in Figure 1. 
Figure 1. Ischemic area on the skin near the carotid arteries and across the distribution of the facial artery.

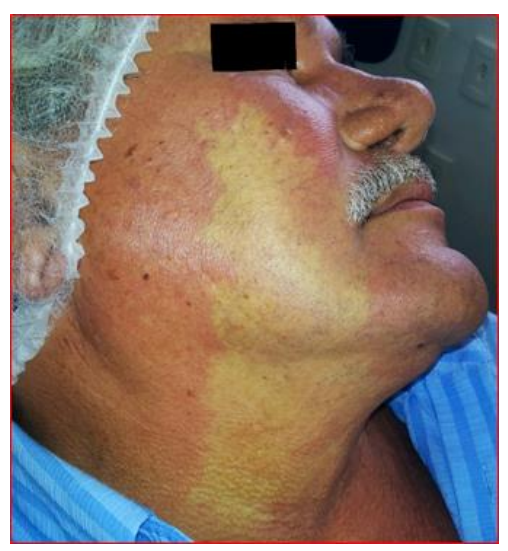

Source: Authors.

The patient reported previous local anesthetic procedures, however, this was the first time that an event of this nature had happened to him. The initial conduct included anxiety control measures. The room cooling system was shut down and the patient was kept under observation until his clinical condition was normalized. According to the treatment algorithm for RS by Laundry (2013), conservative management measures (i.e. hand warming and cold avoidance) were employed and the surgical procedures were performed without further infiltration with local anesthesia. As expected, the patient's face color returned to normal conditions and there was no alteration on his vital signs. The patient recovered well in the post-operative period. Osseointegration of the implant and prosthetic rehabilitation succeeded uneventfully (figure 2). Written informed consent was obtained from the patient for publication of his case and the recommendation of the Declaration of Helsinki were followed accordingly.

Figure 2. Site corresponding to the first lower molar prosthetically rehabilitated with a dental implant.

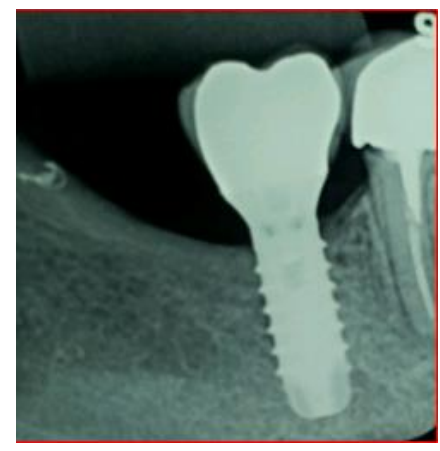

Source: Authors.

\section{Discussion}

Raynaud's syndrome remains a poorly understood clinical condition whose treatment protocol depends on the underlying pathophysiology and severity of symptoms (Landry, 2013).

Landry (2013) also explain that according to the set of signs and symptoms and association with other conditions, RS can be classified into primary or secondary RS. Primary RS is more common in the extremities and is referred as an isolated entity characterized by paresthesia, pain, and burning sensation (Milet et al., 1953), (Kayser et al., 2009). Its treatment consists of performing vasodilatoion (i.e., warming procedure); and patients are advides to live in warmer regions; in addition to avoiding trauma and anxiety control (Pope, 2007), (Jackson, 2006), (Kayser et al., 2009), (Heidrich, 2010), (Marzola, 1999). 
Secondary RS also referred to as Raynaud's phenomenon occurs in association with other conditions or may precede the clinical onset of secondary diseases, most commonly the connective tissue disorders such as Sjögen's syndrome, CREST syndrome, scleroderma, and rheumatoid arthritis (Dixit et al., 2016), (Pope, 2007), (Stanford et al., 1999), (Rankin, 2007).

According to the literature, most patients with RS were managed conservatively by avoiding cold exposure and by performing vasodilation procedures such as warming. Pharmacologic (i.e. calcium channel blockers) Thompson, \& Pope (2005), and surgical procedure such as thoracic sympathectomy are more common in secondary RS cases. and when patients do not respond to simple conservative measures (Landry, 2013). The patient reported in this paper was managed conservatively and did not require additional medication.

Treatment of Raynaud's phenomenon with vasotive drugs such as nifedipine may produce gingival overgrowth and complicate dental treatments (Stanford et al., 1999). Although RS is a rare complication, dental professionals should be able to recognize it and follow the appropriate guidelines available (Marzola, 1999). Even being considered as a rheumatic benign condition (Pope, 2007), (Jackson, 2006), (Kayser et al., 2009), (Heidrich, 2010), RS has implications for dentistry, mainly regarding anxiety control, since anxiety is also reported as a strong psychosomatic component in disease etiology (Milet et al., 1953), (Marzola, 1999). In addition, adrenergic vasoconstrictors (e.g. epinephrine) used in anesthetic solutions may act as a triggering factor for ischemic events in some patients (Landry, 2013)

It is known that articaine is an anesthetic solution with a high diffusion power. Additionally, epinephrine plays an important role to enhance diffusion of molecules of articaine through the oral tissues Lima-Júnior et al., (2009) Lima-Júnior et al., (2013), Malamed (2021) which might have also contributed to the signs and symptoms observed in the present case.

\section{Final Considerations}

Besides understanding the predisposing factors related to RS and its subsequent complications, dental professionals should be aware of the type of anesthetics used, as well as their pharmacokinetics and pharmacodynamics (Marzola, 1999), (Malamed, 2021).

RS may come up as a dramatic and sudden event, associated with pain and burning. Nevertheless, its evolution is benign, so dentists should keep the situation under control and adopt vasodilaton (warming) measures. Patients should also be referred to a general physician for further investigations. Due to the limited number of reports of patients with this syndrome during dental procedures, we suggest that dentists when faced with such cases, report them in articles and research.

\section{Acknowledgments}

We acknowledgement the Coordination for the Improvement of Higher Education Personnel (CAPES, Ministry of Education, Brazil) for granted PhD scholarship to the first and third authors.

\section{References}

Angelis, R., Salaffi, F., \& Grassi, W. (2006). Raynaud's phenomenon: prevalence in an Italian population sample. Clinical Rheumatology, 25(4), 506-510.

Dixit, S., Kalkur, C., Sattur, A. P., Bornstein, M. M., \& Melton, F. (2016). Scleroderma and dentistry: Two case reports. Journal of Medical Case Reports, 10(1), 297 16. Botzoris, V., \& Drosos, A. A. (2011). Management of Raynaud's phenomenon and digital ulcers in systemic sclerosis. Joint, Bone, Spine: Revue Du Rhumatisme, 78(4), 341-346.

Heidrich, H. (2010). Functional vascular diseases: Raynaud's syndrome, acrocyanosis and erythromelalgia. VASA. Zeitschrift Für Gefasskrankheiten, 39(1), $33-41$

Herrick, A. L. (2012). The pathogenesis, diagnosis and treatment of Raynaud phenomenon. Nature Reviews Rheumatology, 8(8), 469-479.

Jackson, C. M. (2006). The patient with cold hands: understanding Raynaud's disease. JAAPA : Official Journal of the American Academy of Physician Assistants, 19(11), 34-38 8. 
Kayser, C., Corrêa, M. J. U., \& Andrade, L. E. C. (2009). Fenômeno de Raynaud. Revista brasileira de reumatologia, 49(1), 48-63.

Kim, S., Fan, F., Chen, R. Y., Simchon, S., Schuessler, G. B., \& Chien, S. (1980). Symposium: 3. Effects of changes in systemic hemodynamic parameters on pulpal hemodynamics. Journal of Endodontics, 6(1), 394-399

Landry, G. J. (2013). Current medical and surgical management of Raynaud's syndrome. Journal of Vascular Surgery, 57(6), 1710-1716.

Lima-Júnior, J.-L., Dias-Ribeiro, E., de Araújo, T.-N., Ferreira-Rocha, J., Honfi-Júnior, E.-S., Sarmento, C.-F. de M., ... de Sousa, M. do S.-C. (2009). Evaluation of the buccal vestibule-palatal diffusion of $4 \%$ articaine hydrochloride in impacted maxillary third molar extractions. Medicina Oral, Patologia Oral y Cirugia Bucal, 14(3), E129-32.

Lima, J. L., Jr, Dias-Ribeiro, E., Ferreira-Rocha, J., Soares, R., Costa, F. W. G., Fan, S., \& Sant'ana, E. (2013). Comparison of buccal infiltration of 4\% articaine with $1: 100,000$ and $1: 200,000$ epinephrine for extraction of maxillary third molars with pericoronitis: a pilot study. Anesthesia Progress, 60(2), 4245 .

Malamed, S. F. Manual de Anestesia Local (2021). GEN Guanabara Koogan, (7th ed).

Marzola, C. Anestesiologia (1999). Pancast, (3rd ed).

Millet, J. A. P., Lief, H., \& Mittelmann, B. (1953). Raynaud's disease; psychogenic factors and psychotherapy. Psychosomatic Medicine, 15(1), 60-65.

Pope, J. E. (2007). The diagnosis and treatment of Raynaud's phenomenon: a practical approach. Drugs, 67(4), 517-525.

Rankin, C. H. (2007). A case report of a patient with Raynaud's phenomenon undergoing multiple endodontic procedures. Journal of Endodontics, 33(2), 187190 .

Stanford, T. W., Jr, Peterson, J., \& Machen, R. L. (1999). CREST syndrome and periodontal surgery: a case report. Journal of Periodontology, 70(5), 536541.

Suter, L. G., Murabito, J. M., Felson, D. T., \& Fraenkel, L. (2005). The incidence and natural history of Raynaud's phenomenon in the community. Arthritis and Rheumatism, 52(4), 1259-1263.

Thompson, A. E., \& Pope, J. E. (2005). Calcium channel blockers for primary Raynaud's phenomenon: a meta-analysis. Rheumatology (Oxford, England), 44(2), 145-150. Coveliers, H. M. E., Hoexum, F., Nederhoed, J. H., Wisselink, W., \& Rauwerda, J. A. (2011). Thoracic sympathectomy for digital ischemia: a summary of evidence. Journal of Vascular Surgery, 54(1), 273-277.

Voulgari, P. V., Alamanos, Y., Papazisi, D., Christou, K., Papanikolaou, C., \& Drosos, A. A. (2000). Prevalence of Raynaud's phenomenon in a healthy Greek population. Annals of the Rheumatic Diseases, 59(3), 206-210. 